\title{
Bloodstream Infections caused by Klebsiella pneumoniae and Serratia marcescens isolates co-harboring NDM-1 and KPC-2.
}

Taniela Bes ( $\sim$ taniela.bes@hms.harvard.edu )

University of Sao Paulo

Debora Nagano

Universidade de Sao Paulo

Roberta Martins

Universidade de Sao Paulo

Ana Paula Marchi

Universidade de Sao Paulo

Lauro Perdigão Neto

Universidade de Sao Paulo

Hermes Higashino

Universidade de Sao Paulo

Gladys Prado

Universidade de Sao Paulo

Thais Guimaraes

Universidade de Sao Paulo

Anna S Levin

Universidade de Sao Paulo

Silvia Costa

Universidade de Sao Paulo

\section{Short report}

Keywords: Enterobacteriaceae, Carbapenem-resistant, blaKPC-2, blaNDM-1, co-harboring

Posted Date: January 29th, 2020

DOI: https://doi.org/10.21203/rs.2.22113/v1

License: @ (i) This work is licensed under a Creative Commons Attribution 4.0 International License. Read Full License

Version of Record: A version of this preprint was published at Annals of Clinical Microbiology and Antimicrobials on August 30th, 2021. See the published version at https://doi.org/10.1186/s12941-021-00464-5. 


\section{Abstract}

Carbapenem-resistant Enterobacteriaceae is a worldwide health problem, however isolates carrying both blaKPC-2 and blaNDM-1 are unusual. Here we describe microbiological and clinical characteristics of five cases of bloodstream infection (BSI) caused by carbapenem-resistant K lebsiella pneumoniae and Serratia marcescens co-harboring blaKPC-2 and blaNDM-1.Of the five blood culture isolates, three from are from hematopoietic stem cell transplantation patients, one from a renal transplant patient, and one from a soft tissue surgical patient. All patients lived in low-income neighborhoods and had no travel history. Despite antibiotic treatment, four of five patients died. The phenotypic assays showed that Meropenem added with either EDTA, PA or both showed increased zone of inhibition in comparison to Meropenem alone. Molecular tests confirmed blaKPC-2 and blaNDM-1 genes, the K. pneumoniae were assigned as ST258 and ST340 by Whole Genome Sequencing.

\section{Introduction}

The increased of Carbapenem resistance in Enterobacteria represents a clinical challenge and a public health problem $(1,2)$. Even though strains carrying multiple carbapenemases have emerged in last years(3), reports of isolates carrying $b / a_{\mathrm{KPC}-2}$ and $b / a_{\mathrm{NDM}-1}$ are unusual. Few cases have been described(4-9), including reports of a burn patient colonized by Klebsiella pneumoniae co-harboring KPC and NDM assigned as ST86(4), a urinary tract infection in a cranioencephalic traumatism patient(5) and three cases of no specify site of infection, in China, caused by K. pneumoniae assigned as ST1, ST147, ST1383(6).

Coproduction of carbapenemases are equally infrequent in Serratia marcescens. Silva et al, 2014(7) described six strains of $S$. marcescens isolated from urine or tracheal aspirate samples producing simultaneously KPC-2 and IMP-10 simultaneously in Brazil.

Routine susceptibility testing cannot precisely predict the presence of Metallo- $\beta$-lactamase (MBLs), and the co-existence of other carbapenemases further aggravates the issue. The aim of this study was to describe microbiological and clinical characteristics of five cases of BSI caused by $K$. pneumoniae ( $\mathrm{N} 4$ ) and Serratia marcescens (N 1) co-harboring KPC-2 and NDM-1.

\section{Results}

The five isolates used in this study were from blood cultures: three from Hematopoietic Stem Cell Transplantat (HSCT) patients, one from a renal transplant patient, and one from a soft tissue surgical patient. All patients lived in low-income neighborhoods in Sao Paulo, with less than eight years of schooling and no history of international travel. Mortality in 14 days of diagnosis of the BSI occurred in three of the five patients. Most of patients were treated with meropenem, tigecycline and colistin, except the $S$. marcescens case which received tigecycline and fosfomycin. Clinical data is shown in the table 1.

Microdilution susceptibility test by Sensititre demonstrated resistance to $\beta$-lactams including Aztreonam, by all isolates (Table 1). Phenotypic tests revealed probable presence of serine carbapenemase and metallo-beta-lactamase as well. Meropenem (MPM) added with either Ethylenediaminetetraacetic acid (EDTA), phenylboronic acid (PBA) or both showed increased zone of inhibition in comparison to Meropenem alone. Three of the five isolates had full growth around the MPM disk alone and the zone of inhibition was higher than 9mm, with double zone of inhibition, when submitted to MPM disks added with EDTA and/or PBA (Table 1). The remaining two isolates, the S. marcescens and a K. pneumoniae (ST340) did not show a difference higher than $4 \mathrm{~mm}$ in the zone of inhibition in any of the combinations.

The PCR analysis detected $b / a_{\mathrm{KPC}-2}$ and $b / a_{\mathrm{NDM}-1}$ genes in all five strains, which were confirmed by Sanger Sequencing. The $K$. pneumoniae isolates were assigned as ST340 and ST258 (Figure 1). Virulence genes related with adhesion, efflux pump, iron acquisition, regulation and secretion system were present in the four K. pneumoniae samples (Table 1).

\section{Discussion}

We report, for the first time in Brazil, the identification of $K$. pneumoniae and $S$. marcescens isolates co-harboring $b / a_{\mathrm{KPC}-2}$ and $b / a_{\mathrm{NDM}-1}$, including two $K$. pneumoniae STs (ST258 and ST340) that have not been previously described, coproducing KPC-2 and NDM-1. The ST258 emerged during the early 2000 s as a hybrid clone created by recombination between ST11 and ST442 and the ST340 which is a single-locus variant of ST11 as well(10). These isolates tend to be pan-resistant, restricting the therapeutic options, particularly to high resistant $S$. marcescens isolates, since they are intrinsic resistance to polymyxins(11).

The dissemination of NDM-1 and KPC-2 in Brazil is of great concern since a Providencia rettgeri isolate carrying NDM-1 was described in the South region in 2013(12) and subsequently in 2014, Rozales et al published a study analyzing 1134 isolates of Enterobacteriaceae among which 11 of them harbored bla NDM${ }_{1}(0.97 \%)(13)$. The most alarming data was that none of these cases had a history of traveling outside Brazil, which might represent local acquisition. Our cases present common characteristics, such as low socioeconomic class, low educational background, severe clinical conditions and poor functional status, already described as risk factors for infection by co-resistant agents $(6,13,14)$. Outside the hospital setting, another concern is the detection of KPC-2-producing K. pneumoniae isolates in Brazilian rivers in urban areas(15).

Our isolates displaye a high-level of resistance to $\beta$-lactams, aminoglycosides, and fluoroquinolones, but initially remained susceptible to tigecycline. In addition, three of them were susceptible to colistin, except the $S$. marcescens which was intrinsically resistant and the $K$. pneumoniae belonging to ST340. A possible reason for this finding is that carbapenem-resistant enterobacteria isolates carrying $b / a_{\mathrm{NDM}-1}$ are more likely to be resistant to several antibiotics. They are often accompanied by other genes, which are resistant to $\beta$-lactams, fluoroquinolones and aminoglycosides(16). 
The isolate which was colistin resistant did not harbor plasmidial mediated resistance genes nor chromosomal mutation on the WGS analyzes. We speculate that the resistance derived from virulence genes encoded at Lipopolysaccharide (LPS) rfb locus, wzm and wzt codify the proteins to form an ATP-binding cassette (ABC) transporter responsible for export O-antigenic polysaccharide (O-PS), a glycan necessary to synthetize cell surface LPS. The ABC transporters are formed to a specific 0-PS. The Wzt protein dictates the specificity of the substrate and the glycan chain length, which serves as an export signal recognized by the $\mathrm{ABC}$ transporter. The $K$. pneumoniae isolate 1581 carries just the wzm gene therefore our hypothesis is that lacking wzt trapped the transporter in a state incapable to complete the O-PS export. It might explain the colistin resistance, specifically because in K. pneumoniae the cytosolic glycan synthesis and export are obligatorily coupled $(17,18)$.

This study shows that BSI caused by carbapenem-resistant enterobacteria coproducing KPC-2 and NDM-1 results in high mortality. Based on the evidence presented here, significant effort is required to identify these isolates with both resistance genes in the routine and research laboratory. To complicate matters further, there may be a correlation between high-resistance bacteria found in urban rivers in Sao Paulo and those found in hospitals. The detection of samples co-harboring KPC-2 and NDM-1 remains unsatisfactory with phenotypic tests. As a result, routine microbiology laboratories must be on alert for samples coharboring these mechanisms. Early detection, therefore, becomes extremely important for the implementation of infection control measures and epidemiological surveillance.

\section{Methods}

Four carbapenem-resistant KP and one carbapenem-resistant S. marcescens were obtained from blood cultures from patients hospitalized at Hospital das Clínicas, Faculdade de Medicina da Universidade de São Paulo a tertiary teaching hospital in Sao Paulo, Brazil comprised of 2,200 beds.

The five isolates were from the Microbiology Laboratory samples bank and were involved in previous studies, when informed consent term was obtained. This is a retrospective study and all methods were performed in accordance with the guidelines and regulations, approved by the Ethics Committee of Hospital das Clinicas of University of São Paulo, Brazil. Data was consolidated and analyzed, and patients' identity was confidential. The approval numbers are $1.310 .231,2.158 .859$ and 2.452 .282 .

Vitek II (BioMerieux-France) was used to identify the isolates species until February 2015, since then we have been using the Matrix-assisted laser desorption ionization-time of flight (MALD-TOF/Bruker) as well.

The minimum inhibitory concentration (MIC) was tested by Sensititre (ThermoFisher Diagnostics-) to Aztreonam, Meropenem, Imipenem, Colistin, Amikacin and Tigecycline. The susceptibility test results were interpreted according to the criteria recommended by CLSI. Escherichia coli isolate ATCC 25922 was used as the quality control of the test.

Additional phenotypic analysis was done to characterize the resistance using disk diffusion (DD) method, cutoff according to CLSI: Meropenem commercial disks containing $10 \mu \mathrm{g}$ were added with $0.05 \mathrm{M}$ of Ethylenediaminetetraacetic acid (Sigma-Aldrich, St. $115 \mathrm{Louis,} \mathrm{MO}$ ) and/or $20 \mu \mathrm{g} \mathrm{ml} \mathrm{l}^{-1}$ of phenylboronic acid (Sigma-Aldrich, St. Louis, MO). According to Migliavacca et al (2002)(19), a difference of $\geq 4 \mathrm{~mm}$ in the zone of inhibition diameter was used as criteria to determine whether the isolate produced serine carbapenemase, metallo-beta-lactamase or both in presence of EDTA, PBA or either, respectively, when compared to the MPM disk alone. E. coli ATCC 25922 was used as negative quality control.

To detect carbapenemases genes, we performed PCR using previously described primers for $b / a_{\mathrm{KPC}-2}$ and $b / a_{\mathrm{NDM}-1}$ genes(20). The amplicons were submitted to Sanger Sequencing using MegaBACE 1000 (ABI 3730 DNA Analyser; Applied Biosystems, Alameda, CA) to confirm the gene identity.

Whole Genome Sequencing (WGS) was done by Illumina MiSeq. For the WGS, total DNA was extracted with Illustra bacteria genomicPrep Mini Spin Kit (GE Healthcare Life Sciences). DNA quality was verified using the NanoDrop spectrophotometer (Thermo Scientific, Delaware, USA). The whole genome was sequenced by MiSeq IlluminaTM. Libraries were prepared with the commercial kit Nextera XT IlluminaTM according to manufacturer's instructions. The quality of the files generated in the sequencing was evaluated by FastQC v.0.11.3 and Trimmomatic v.0:33. The genome assembly was performed using Velvet Optimiser v.2.2.5. The genome was annotated with Prokka v.1:11. The ST of the isolates was checked by MLSTfinder tool (Larsen et al, 2012) and confirmed in the database PubMLST (http://pubmlst.org). The gene bla KPC-2 $_{2}$ was manually investigated using Artemis v.16.0.0.

\section{Declarations}

\section{Ethics approval and consent to participate}

The five isolates were from the Microbiology Laboratory samples bank and were involved in previous studies, when informed consent term was obtained. This is a retrospective study and all methods were performed in accordance with the guidelines and regulations, approved by the Ethics Committee of Hospital das Clinicas of University of São Paulo, Brazil.

\section{Consent for publication}

As the previous item.

\section{Availability of data and materials}

The data used to support the findings of this study are all included within the article and references.

\section{Competing interests}


The authors certify that they have NO affiliations with or involvement in any organization or entity with any financial interest in the subject matter or materials discussed in this manuscript.

\section{Funding}

No external founding were neded. The study was performed with internal grants from the Medical Investigation laboratory (LIM-49)

\section{Authors' contributions}

Taniela Bes wrote the main manuscript and the genotypic and phenotypic analyses;

Debora Nagano worked phenotypic and genotypic analyzes, as well as with the whole genome sequencing analyzes;

Roberta Martins worked with the whole genome sequencing analyzes;

Ana Paula Marchi worked phenotypic and genotypic analyzes;

Hermes Higashino, Gladys Prado and Thais Guimaraes were the infectious diseases attendants who manage the patient clinically;

Lauro Perdigão Neto, Anna Levin and Silvia Costa were the main reviewers;

All authors reviewed the manuscript

\section{Acknowledgements}

To all thepatients and physichian envolved as well as to the microbiology laboratory team.

\section{References}

1. Center for Health Statistics N. Health, United States, 2014 (5/2015) [Internet]. 2014 [cited 2019 Nov 3]. Available from: https://www.cdc.gov/nchs/data/hus/hus14.pdf

2. ANVISA. Agência Nacional de Vigilância Sanitária. Programa Nacional de Prevenção e Controle de Infecções Relacionadas à Assistência à Saúde (PNPCIRAS) 2016 - 2020. 2016; Available from: http://portal.anvisa.gov.br/documents/33852/3074175/PNPCIRAS+2016-2020/f3eb5d51-616c-49fa8003-0dcb8604e7d9

3. Walsh TR, Toleman MA, Poirel L, Nordmann P. Metallo- $\beta$-lactamases: The quiet before the storm? Clin Microbiol Rev. 2005;18(2):306-25.

4. Wei D-D, Wan L-G, Liu Y. Draft Genome Sequence of an NDM-1- and KPC-2-Coproducing Hypervirulent Carbapenem-Resistant Klebsiella pneumoniae Strain Isolated from Burn Wound Infections. Genome Announc [Internet]. 2018 Mar 29 [cited 2019 Nov 3];6(13). Available from: http://www.ncbi.nlm.nih.gov/pubmed/29599157

5. Wang J, Yuan M, Chen H, Chen X, Jia Y, Zhu X, et al. First Report of Klebsiella oxytoca Strain Simultaneously Producing NDM-1, IMP-4, and KPC-2 Carbapenemases. Antimicrob Agents Chemother [Internet]. 2017 Sep [cited 2019 Nov 3];61(9). Available from: http://www.ncbi.nlm.nih.gov/pubmed/28674063

6. Yan J, Pu S, Jia X, Xu X, Yang S, Shi J, et al. Multidrug resistance mechanisms of Carbapenem resistant Klebsiella pneumoniae strains isolated in Chongqing, China. Ann Lab Med. 2017;37(5):398-407.

7. Silva KE, Cayô R, Carvalhaes CG, Patussi Correia Sacchi F, Rodrigues-Costa F, Ramos Da Silva AC, et al. Coproduction of KPC-2 and IMP-10 in carbapenem-resistant Serratia marcescens isolates from an outbreak in a Brazilian Teaching Hospital. J Clin Microbiol. 2015;53(7):2324-8.

8. Pereira PS, Borghi M, Albano RM, Lopes JCO, Silveira MC, Marques EA, et al. Coproduction of NDM-1 and KPC-2 in Enterobacter hormaechei from Brazil. Microb Drug Resist. 2015;21(2):234-6.

9. Quiles MG, Rocchetti TT, Fehlberg LC, Kusano EJU, Chebabo A, Pereira RMG, et al. Unusual association of NDM-1 with KPC-2 and armA among Brazilian Enterobacteriaceae isolates. Brazilian J Med Biol Res. 2015;48(2):174-7.

10. Munoz-Price LS, Poirel L, Bonomo RA, Schwaber MJ, Daikos GL, Cormican M, et al. Clinical epidemiology of the global expansion of Klebsiella pneumoniae carbapenemases. Lancet Infect Dis [Internet]. 2013 Sep [cited 2019 Nov 3];13(9):785-96. Available from:

http://www.ncbi.nlm.nih.gov/pubmed/23969216

11. Kazi M, Shetty A, Rodrigues C. The Carbapenemase Menace: Do Dual Mechanisms Code for More Resistance? Infect Control Hosp Epidemiol [Internet]. 2015 Jan 5 [cited 2019 Nov 3];36(1):116-7. Available from: http://www.ncbi.nlm.nih.gov/pubmed/25627774

12. Carvalho-Assef APD, Pereira PS, Albano RM, Beriao GC, Chagas TPG, Timm LN, et al. Isolation of NDM-producing Providencia rettgeri in Brazil. J Antimicrob Chemother [Internet]. 2013 Dec 1 [cited 2019 Nov 3];68(12):2956-7. Available from: http://www.ncbi.nlm.nih.gov/pubmed/23869051

13. Rozales FP, Ribeiro VB, Magagnin CM, Pagano M, Lutz L, Falci DR, et al. Emergence of NDM-1-producing Enterobacteriaceae in Porto Alegre, Brazil. Int J Infect Dis [Internet]. 2014 Aug [cited 2019 Nov 3];25:79-81. Available from: http://www.ncbi.nlm.nih.gov/pubmed/24857802

14. Jia X, Dai W, Ma W, Yan J, He J, Li S, et al. Carbapenem-resistant E. cloacae in Southwest China: Molecular analysis of resistance and risk factors for infections caused by NDM-1-producers. Front Microbiol. 2018;9(APR):1-11.

15. Oliveira S, Moura RA, Silva KC, Pavez M, Mcculloch JA, Dropa M, et al. Isolation of kPC-2-producing klebsiella pneumoniae strains belonging to the highrisk multiresistant clonal complex 11 (ST437 and ST340) in urban rivers. J Antimicrob Chemother. 2014;69(3):849-52. 
16. Kumarasamy KK, Toleman MA, Walsh TR, Bagaria J, Butt F, Balakrishnan R, et al. Emergence of a new antibiotic resistance mechanism in India, Pakistan, and the UK: A molecular, biological, and epidemiological study. Lancet Infect Dis. 2010;10(9):597-602.

17. Cuthbertson L, Kimber MS, Whitfield C. Substrate binding by a bacterial ABC transporter involved in polysaccharide export. Proc Natl Acad Sci [Internet]. 2007 Dec 4 [cited 2019 Nov 3];104(49):19529-34. Available from: http://www.ncbi.nlm.nih.gov/pubmed/18032609

18. Davidson AL, Dassa E, Orelle C, Chen J. Structure, Function, and Evolution of Bacterial ATP-Binding Cassette Systems. Microbiol Mol Biol Rev. 2008;72(2):317-64.

19. Migliavacca R, Docquier J-D, Mugnaioli C, Amicosante G, Daturi R, Lee K, et al. Simple microdilution test for detection of metallo-beta-lactamase production in Pseudomonas aeruginosa. J Clin Microbiol [Internet]. 2002 Nov [cited 2019 Nov 3];40(11):4388-90. Available from: http://www.ncbi.nlm.nih.gov/pubmed/12409438

20. Rizek C, Fu L, dos Santos LC, Leite G, Ramos J, Rossi F, et al. Characterization of carbapenem-resistant Pseudomonas aeruginosa clinical isolates, carrying multiple genes coding for this antibiotic resistance. Ann Clin Microbiol Antimicrob. 2014;13(1):4-8.

\section{Table}

Table 1: Clinical characteristics, outcome, phenotypic analyze, virulence and resistance-associated genes identified by whole genome sequence.

M: Meropenem ME: Meropenem + EDTA MA: Meropenem + Phenylboronic Acid (PBA) MEA: Meropenem + EDTA + PBA

\begin{tabular}{|c|c|c|c|c|c|c|c|c|}
\hline $\begin{array}{l}\text { Isolate } \\
\qquad \text { MLST }\end{array}$ & $\begin{array}{l}\text { Underlying } \\
\text { diseases/Approach }\end{array}$ & $\begin{array}{l}\text { Treatment and } \\
\text { outcome }\end{array}$ & $\begin{array}{l}\text { Phenotypic Tests - } \\
\text { serina- } \beta- \\
\text { lactamases (DD } \\
\mathrm{mm} \text { ) }\end{array}$ & $\begin{array}{l}\text { Phenotypic Tests - } \\
\text { MBLs (DD mm) }\end{array}$ & Carbapenembac & $\begin{array}{l}\text { beta- } \\
\text { Lactamics } \\
\text { resist } \\
\text { genes }\end{array}$ & $\begin{array}{l}\text { Aztreonam } \\
\text { (MIC) }\end{array}$ & $\begin{array}{l}\mathrm{Me} \\
(\mathrm{Ml}\end{array}$ \\
\hline $\begin{array}{l}\text { K. } \\
\text { pneumoniae } \\
(1411) \\
\text { 10/19/2012 } \\
\text { ST340 }\end{array}$ & $\begin{array}{l}\text { Myelodysplastic } \\
\text { syndrome Leukocytes: } \\
100 \text { Neutrophils: } 0 \\
\text { Allogeneic } \\
\text { BMT (10/11/2012) }\end{array}$ & $\begin{array}{l}\text { Meropenem + } \\
\text { Colistin } \\
\text { Death } 2 \\
\text { days after } \\
\text { blood culture- } \\
\text { positive }\end{array}$ & $\begin{array}{l}\text { IMP: } 0 \\
\text { ERT: } 0 \\
\text { MPM: } 0 \\
\text { MPM+PBA: } 14 \mathrm{~mm} \\
\text { MPM+EDTA+PBA: } \\
\text { 17mm }\end{array}$ & $\begin{array}{l}\text { IMP: } 0 \\
\text { ERT: } 0 \\
\text { MPM: } 0 \\
\text { MPM+EDTA: } 0 \\
\text { (phantom zone } \\
\text { 14) } \\
\text { MPM+EDTA+PBA: } \\
\text { 17mm }\end{array}$ & Positive & $\begin{array}{l}\text { blaCTX-M- } \\
15 \\
\text { blaKPC-2 } \\
\text { blaSHV- } \\
11 \\
\text { blaTEM- } \\
1 \mathrm{~B}\end{array}$ & $\geq 32[\mathrm{R}]$ & $\geq 1$ \\
\hline $\begin{array}{l}\text { K. } \\
\text { pneumoniae } \\
(1581) \\
12 / 14 / 2012 \\
\quad \text { ST340 }\end{array}$ & $\begin{array}{l}\text { Severe aplastic } \\
\text { anemia } \\
\text { Leukocytes: } 100 \\
\text { Neutrophils: } 0 \\
\text { Not related } \\
\text { allogeneic TCTH } \\
(12 / 09 / 2012)\end{array}$ & $\begin{array}{l}\text { Meropenem + } \\
\text { Colistin } \\
\text { Death } 2 \text { days } \\
\text { after blood } \\
\text { culture- } \\
\text { positive }\end{array}$ & $\begin{array}{l}\text { IMP: 23mm } \\
\text { 16mm MRT: } \\
\text { 20mm MPM: } \\
\text { MPM+PBA: 23mm } \\
\text { MPM+EDTA+PBA: } \\
\text { 23mm }\end{array}$ & $\begin{array}{l}\text { IMP: } 23 \mathrm{~mm} \text { ERT: } \\
\text { 16mm MPM: } \\
\text { 20mm } \\
\text { MPM+EDTA: } \\
\text { 21mm } \\
\text { MPM+EDTA+PBA: } \\
\text { 23mm }\end{array}$ & Positive & $\begin{array}{l}\text { blaKPC-2 } \\
\text { blaSHV- } \\
11\end{array}$ & $\geq 32[\mathrm{R}]$ & $4[\mathrm{~F}$ \\
\hline $\begin{array}{l}\text { K. } \\
\text { pneumoniae } \\
\text { (4301) } \\
10 / 16 / 2014 \\
\text { ST340 }\end{array}$ & $\begin{array}{l}\text { Non-Hodgkin } \\
\text { lymphoma } \\
\text { Peripheral T-cell } \\
\text { lymphoma } \\
\text { Leukocytes: } 3,33 \\
\text { Neutrophils: } 2,43 \\
\text { Autologous BMT } \\
\text { 9/17/2014 }\end{array}$ & $\begin{array}{l}\text { Meropenem + } \\
\text { Colistin } \\
\text { Discharge } \\
\text { from hospital } \\
23 \text { days after } \\
\text { blood culture- } \\
\text { positive, for a } \\
\text { total of } 64 \\
\text { days } \\
\text { hospitalization }\end{array}$ & $\begin{array}{l}\text { IMP: } 0 \\
\text { ERT: } 0 \\
\text { MPM: } 0 \\
\text { MPM+PBA: } 13 \mathrm{~mm} \\
\text { MPM+EDTA+PBA: } \\
\text { 18mm }\end{array}$ & $\begin{array}{l}\text { IMP: } 0 \\
\quad \text { ERT: } 0 \\
\text { MPM: } 0 \\
\text { MPM+EDTA: } 10 \\
\text { (phantom zone } \\
\text { 14) } \\
\text { MPM+EDTA+PBA: } \\
\text { 18mm }\end{array}$ & Positive & $\begin{array}{l}\text { blaKPC-2 } \\
\text { blaSHV-5 } \\
\text { blaSRT-2 }\end{array}$ & $\geq 32[R]$ & $\geq 1$ \\
\hline $\begin{array}{l}S . \\
\text { marcescens } \\
(1756) \\
6 / 14 / 2013\end{array}$ & $\begin{array}{l}\text { Necrotizing fasciitis } \\
\text { Amputation of the } \\
\text { right arm }(05 / 31 / 13) \\
\text { Complication: } \\
\text { Ischemic cecum } \\
\text { perforation } \\
(6 / 07 / 2013)\end{array}$ & $\begin{array}{l}\text { Ciprofloxacin } \\
+ \text { Clindamycin } \\
\text { Tigecycline } \\
+ \text { Fosfomycin } \\
\text { Death } 11 \\
\text { days after } \\
\text { blood culture- } \\
\text { positive }\end{array}$ & $\begin{array}{l}\text { IMP: } 13 \mathrm{~mm} \\
\text { 17mm } \\
\text { MPT: } \\
\text { 23mm } \\
\text { MPM+PBA: } 25 \mathrm{~mm} \\
\text { MPM+EDTA+PBA: } \\
26 \mathrm{~mm}\end{array}$ & $\begin{array}{l}\text { IMP: } 13 \mathrm{~mm} \text { ERT: } \\
\text { 17mm MPM: } \\
\text { 23mm } \\
\text { MPM+EDTA: } \\
\text { 19mm } \\
\text { MPM+EDTA+PBA: } \\
26 \mathrm{~mm}\end{array}$ & Positive & $\begin{array}{l}\text { blaKPC-2 } \\
\text { blaSHV-5 } \\
\text { blaSRT-2 }\end{array}$ & $\geq 32[R]$ & $4[\mathrm{~F}$ \\
\hline $\begin{array}{l}\text { K. } \\
\text { pneumoniae } \\
(4990) \\
10 / 21 / 16 \\
\quad \text { ST258 }\end{array}$ & $\begin{array}{l}\text { Kidney transplant due } \\
\text { Chronic Kidney } \\
\text { Disease } \\
\text { (10/13/16) } \\
\text { Urinary tract infection } \\
\text { (10/20/16) } \\
\text { Graft } \\
\text { Nephrectomy } \\
(11 / 23 / 16)\end{array}$ & $\begin{array}{l}\text { Ceftazidime + } \\
\text { Avibactam } \\
\text { Death } 40 \\
\text { days after } \\
\text { blood culture- } \\
\text { positive }\end{array}$ & $\begin{array}{l}\text { IMP: } 6 \mathrm{~mm} \\
\text { ERT: } 0 \\
\text { MPM: } 0 \\
\text { (phantom zone 7) } \\
\text { MPM+PBA: 14mm } \\
\text { MPM+EDTA+PBA: } \\
\text { 16mm (phantom } \\
\text { zone 20) }\end{array}$ & $\begin{array}{l}\text { IMP: } 6 \mathrm{~mm} \\
\text { ERT: } 0 \\
\text { MPM: } 0 \text { (phantom } \\
\text { zone 7) } \\
\text { MPM+EDTA: 9mm } \\
\text { (phantom zone } \\
\text { 20) } \\
\text { MPM+EDTA+PBA: } \\
\text { 16mm (phantom } \\
\text { zone 20) }\end{array}$ & Positive & $\begin{array}{l}\text { blaCTX-M- } \\
14 \\
\text { blaKPC-2 } \\
\text { blaSHV- } \\
11 \\
\text { blaTEM- } \\
1 \mathrm{~B}\end{array}$ & $\geq 32[R]$ & $\geq \epsilon$ \\
\hline
\end{tabular}




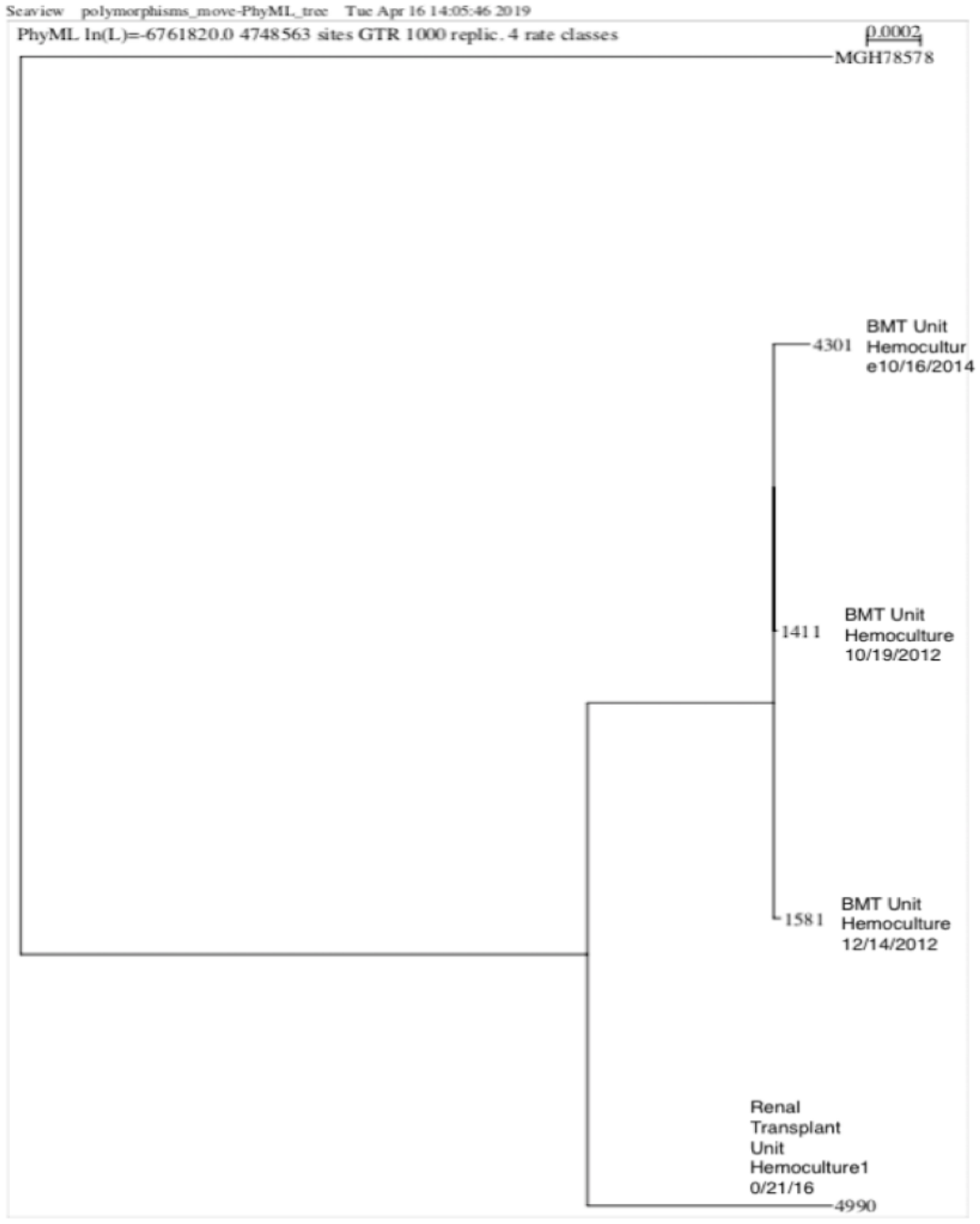

\section{Figure 1}

Phylogenies of K. pneumoniae showing the same clone ST340 in the BMT unit and the globally disseminated, ST258 in Renal Transplant Unit. 